\title{
Microbial EC50 Subject Result
}

National Cancer Institute

\section{Source}

National Cancer Institute. Microbial EC50 Subject Result. NCI Thesaurus. Code C139117.

A measurement of titer of a microbial organism that has been exposed to the concentration of a specific drug expected to produce 50 percent inhibition of the population growth or replication of a microbial organism. 